\title{
RAINING ON THE PARADE OF HORRIBLES: OF SLIPPERY SLOPES, FAUX SLOPES, AND JUSTICE SCALIA'S DISSENT IN LAWRENCE V. TEXAS
}

\author{
RUTH E. STERNGLANTZ ${ }^{\dagger}$
}

\section{INTRODUCTION}

Anyone else bored to tears with the "slippery slope" arguments against gay marriage? Since few opponents of homosexual unions are brave enough to admit that gay weddings just freak them out, they hide behind the claim that it's an inexorable slide from legalizing gay marriage to having sex with penguins outside JC Penney's.

—Dahlia Lithwick ${ }^{1}$

The slippery slope is in some ways a helpful metaphor, but as with many metaphors, it starts by enriching our vision and ends by clouding it.

-Eugene Volokh ${ }^{2}$

On June 26, 2003, the Supreme Court delivered its opinion in Lawrence $v$. Texas, ${ }^{3}$ a case challenging the constitutionality of a state statute criminalizing homosexual (but not heterosexual) sodomy. ${ }^{4}$ The Court held that the Texas statute (and, by implication, others like

${ }^{\dagger}$ B.A. 1986, Brooklyn College, CUNY; Ph.D. 1998, New York University; J.D. Candidate 2005, University of Pennsylvania. I am grateful to Professor Catherine Struve, Sarah Greenberger, and Tim Kerr, whose suggestions and advice have improved this essay, and to Professors Robert R. Raymo and Mary Carruthers, who taught me how to talk about language. Len Barot was the first reader of my first draft; her encouraging response at a vulnerable moment was a great gift. The care and good humor of the editors at the University of Pennsylvania Law Review made the formal editorial process both productive and painless. All remaining errors are my own.

${ }^{1}$ Dahlia Lithwick, Slippery Slop: The Maddening "Slippery Slope" Argument Against Gay Marriage, SLATE, May 19, 2004 at http://slate.msn.com/id/2100824/.

2 Eugene Volokh, The Mechanisms of the Slippery Slope, 116 HARV. L. REV. 1026, 1137 (2003).

539 U.S. 558, 123 S. Ct. 2472 (2003).

${ }^{4}$ Id. at 2476. 
it) was unconstitutional, violating petitioners' due process rights, ${ }^{5}$ and thus overturning its 1986 ruling in Bowers v. Hardwick. ${ }^{6}$ Justice Scalia, writing in dissent, warned that Bowers was a necessary barrier to the invalidation of numerous state laws regulating morals offenses and that Lawrence was, therefore, the first step onto a slippery slope that would lead courts to legalize a parade of sexual-conduct horribles. ${ }^{7}$ Justice Scalia offered no legal reasoning to bolster this emotional appeal, a continuation of his baldly homophobic dissent in Romer v. Evans. ${ }^{8}$ This Comment examines the slippery slope argument, as used in judicial opinions, so as to distinguish Justice Scalia's seeming use of this rhetorical technique from what I will demonstrate are its legitimate uses.

The slippery slope argument is a mainstay of legal reasoning and disputation. ${ }^{9}$ As suggested by Professor Eugene Volokh in his recent anatomy of the technique, "the most useful definition of a slippery slope is one that covers all situations where decision $A$, which you might find appealing, ends up materially increasing the probability that others will bring about decision $B$, which you oppose." ${ }^{, 10}$ In some

${ }^{5}$ Id. at 2484.

${ }^{6} 478$ U.S. 186, 196 (1986).

${ }^{7}$ Lawrence, 123 S. Ct. at 2490.

${ }^{8}$ See 517 U.S. 620, 644 (1996) (Scalia, J., dissenting) (analogizing Coloradans' right to disapprove of homosexuals to, inter alia, the right to disapprove of murder, cruelty to animals, and polygamy).

9 See Eugene Volokh, supra note 2, at 1029-30 (describing, in exhaustive detail, the legal uses of slippery slope arguments); Frederick Schauer, Slippery Slopes, 99 HARV. L. REV. 361, 364 (1985) (observing the pervasiveness of the slippery slope argument in legal argument); see also Eric Lode, Comment, Slippery Slope Arguments and Legal Reasoning, 87 CAL. L. REV. 1469, 1471 (1999) (noting the centrality of slippery slope arguments to "many legal debates"); Diane Meulemans, Comment, Approaching the Slope: Processes and Outcomes of the Use of the Slippery Slope in Legal Opinions, 14 WIS. WOMEN's L.J. 105, 106 (1999) (musing on the basis of the "popularity of the slippery slope"). Beyond the realm of the law, the slippery slope has been a subject of great interest to philosophers, both of logic and of ethics. The most useful and comprehensive of these studies is Douglas WALTON, SLIPPERY SLOPE ARgumENTS (1992). Also of interest are DAVID LAMb, Down the SLIPPERY Slope: ARguing IN APPliEd ETHICS, at vii (1988) (describing the use of slippery slope arguments in policy debates related to medical ethics); ROY A. SORENSON, BLINDSPOTS 398-438 (1988) (discussing the slippery slope fallacy from the point of view of "blindspots," or defective mathematical inductions); and Wibren van der Burg, The Slippery Slope Argument, 102 ETHICS 42, 43 (1991) (drawing a distinction between slippery slope arguments occurring in the "context of law" and those occurring in the "context of morality"). For a recent theorization of the slippery slope argument through an economist's lens, see generally Mario J. Rizzo \& Douglas Glen Whitman, The Camel's Nose Is in the Tent: Rules, Theories, and Slippery Slopes, 51 UCLA L. REV. 539 (2003).

${ }^{10}$ Volokh, supra note 2, at 1030 (italicization added). 
sense, of course, this problem is inscribed in the very nature of judicial decision making. Reasoning by means of precedent means, on a fundamental rhetorical level, that most judicial decisions are themselves the products of one or several earlier decisions that set the course to the present case. ${ }^{11}$ And every judicial decision then becomes grist for the mill, potentially setting precedent for any number of future judicial decisions. ${ }^{12}$ What, then, prevents the fear of the slippery slope from paralyzing the entire adjudicative process, from becoming not a slope but a giant black hole whose gravity absorbs legal reasoning by means of reductio ad absurdum? ? $^{13}$ Probably nothing, if Volokh's definition is maintained-except the acknowledgment that for the designation "slippery slope argument" to be useful, it must describe only a subset of all arguments leading to judicial decisions and not (as it might) the entire field.

To refine Volokh's definition, then, let us say that when constructing a slippery slope argument, the arguer necessarily foregrounds not the present case (that is, the case now before the court) but a future case that is to be avoided: specifically, a future case whose dangerous outcome can be constructed as proximate to the outcome of the present case. ${ }^{14}$ Indeed, speaking of slippery slopes generally and not only

${ }^{11}$ Cases of first impression may be the broad exception to this generalization; but even there, judges typically cast their nets wide to analogize the present case to some prior decision. See, e.g., Pierson v. Post, 3 Cai. R. 175, 181-82 (N.Y. Sup. Ct. 1805) (appealing to Roman law regarding ownership of wild creatures). Similarly, as in Lawrence, when a court rules against the tide of stare decisis and overturns an earlier decision, analogy may still serve as a foundation for the new law being forged. Lawrence, 123 S. Ct. at 2481 (referencing the British Parliament's Wolfenden Report and a case decided by the European Court of Human Rights with regard to the legalization of "consensual homosexual conduct").

${ }^{12}$ See, for example, Volokh's description of how judicial slippery slope arguments work: "[J] udicial decision $A$ would 'set a precedent' for decision B." Volokh, supra note 2, at 1064-71 (italicization added).

${ }^{13}$ That is, the process of disproving an argument "by showing that it leads to a ridiculous conclusion.” BLACK'S LAW DICTIONARY 1283 (7th ed. 1999). Diane Meulemans gives an amusing description of the advice given to her when she began law school, by older and wiser friends who had already been down that road. They suggested that if ever she was caught without a response during a professor's Socratic quizzing, she should defer to the slippery slope. Meulemans, supra note 9 , at 105 . She was shocked to discover that lawyers and judges - and not just clueless first-year law students-make ample use of the device, and wondered whether "the popularity of the slippery slope is based on its nebulous and amorphous character so the reader never really knows what exactly the writer is saying?” Id. at 106.

${ }^{14}$ As Walton observes:

It is characteristic of all slippery slope arguments that a dangerous outcome of some contemplated course of action is warned of. But the slippery slope argument is more than just a warning. The dangerous outcome is put forward 
in the legal context, the Canadian philosopher Douglas Walton has noted that "the slippery slope argument is commonly used in critical discussion arising from deliberation to try to persuade someone not to do something he is contemplating. In many instances, as such, it is a reasonable argument, fulfilling a legitimate function in an argumentative dialogue." ${ }^{15}$ So a slippery slope argument is a legitimate argument. But its power lies in the fact that it is more than a rational argument. It is a rhetorical technique designed to combine rational argument with emotional appeal, "an ominous or threatening warning about alleged government policies or intentions that most of the audience of the speech would be likely to view with alarm." ${ }^{.16}$ In the context of judicial opinions, a slippery slope argument highlights the dire effects of proximately potential future decisions that are likely to result from the present case. ${ }^{17}$ And the slippage of the slippery slope argument comes from amplifying "likelihood" to the point of necessity. ${ }^{18}$ That is, someone appealing to the danger of the slippery slope seeks to convince her audience that if the present case is decided in a particular way, stare decisis will lock future courts into certain (implicitly unpalatable) decisions.

To be fair, none of us can predict the future, and we exercise the elision between "what will probably happen" and "what will definitely happen" on a regular basis. Indeed, as an ethical philosopher reminds us, it is that gap that makes the slippery slope argument so urgent:

as a reason for not taking a first step in the contemplated course of action.

WALTON, supra note 9 , at 1.

${ }^{15} I d$. at 19.

${ }^{16} I d$. at 175 .

${ }^{17}$ See, for example, Roy Sorenson's suggestion that

[h]ypothetical slippery slope arguments are the rule in deliberative contexts.

For here the point of exhibiting a slippery slope is to influence a decision. Usually this is done by presenting a slope that has a bad bottom. The arguer tries to dissuade us from taking the first step that will send us tumbling to the bottom. ... Hypothetical slippery slope arguments dissuade by convincing the audience that an apparently acceptable state will lead (by degrees) to an obviously unacceptable state. Once the audience assents to this consequence, the choice becomes an all or nothing affair.

SORENSON, supra note 9 , at 400 .

${ }^{18}$ As Maria Failinger notes, such amplification is the hallmark of Justice Scalia's opinions, and she scolds Justice Scalia for using various rhetorical tactics (including slippery slope arguments) for no reason other than to "engage [his] reader's paranoia." Marie A. Failinger, Not Mere Rhetoric: On Wasting or Claiming Your Legacy, Justice Scalia, 34 U. TOL. L. REV. 425, 483-93 (2003). 
In the absence of absolute knowledge and consequently absolute control over the consequences of our actions and decisions, we cannot afford to ignore the possible misuses of proposed reforms. Philosophers live in a world of clear-cut distinctions, where conceptual boundaries are easily identified. The real world, however, does not conform to such idealisations-although such distinctions may be a necessary means of coping with the world. When exponents of the slippery slope argument appeal to the indeterminateness of certain concepts they draw attention to an aspect of truth and reality which may be obscured by those seeking to impose clear-cut distinctions upon the world. ${ }^{19}$

If we did indeed have perfect foreknowledge of the results of our actions, what might occur at some point down the road would pose an empty threat. It is precisely because we are aware that our behavior may have unintended unpleasant results that we cannot foresee that slippery slope arguments have power to curb present behavior. ${ }^{20}$

So, all judicial opinions might slide down the slippery slope, but they do not. Only some arguments in some cases get tagged as slippery slope arguments, under that eponymous rubric or one of the other pithy labels_-camel's nose," "foot in the door," "thin edge of the wedge," "parade of horribles" ${ }^{, 22}$ - deployed to metaphorically describe their operation. But sometimes, a judicial argument that looks like a slippery slope argument-like an argument that combines logical reasoning with emotion-is in fact not a logical, legal argument at all. Sometimes, the probably/definitely dangerous future warned of by the jurist posing the argument is, in fact, foreclosed by the present case. That is, not only would the present case not be a first step towards the undesirable future case being warned of, but the very rule of law established by the present case distinguishes it from that hypothetical future case. Sometimes there is no slope, no camel, no wedge, no parade.

In this Comment, I will explore these "faux slopes" strictly within the context of U.S. Supreme Court opinions. I will demonstrate that these arguments—cloaked in the rhetoric of the law-are often found

${ }^{19}$ LAMB, supra note 9, at 120.

${ }^{20}$ For another instance of fear of the unforeseeable curbing present behavior, see Hamlet's soliloquy on his failure to expeditiously carry out the Ghost's bidding. WiLliAM SHAKESPEARE, HAMLET act 3, sc. 1 ("[T] he dread of something after death ... makes us rather bear those ills we have, $[\mathrm{t}]$ han fly to others that we know not of . ...”).

${ }^{21}$ See, e.g., Schauer, supra note 9, at 361 (listing these labels and reminding us that "regardless of the term employed, the phenomenon referred to is the same").

${ }^{22}$ See, e.g., Antonin Scalia, Assorted Canards of Contemporary Legal Analysis, 40 CASE W. RES. L. REV. 581, 590-93 (1990) (discussing "the familiar parade of horribles"). 
in cases where status is at stake. ${ }^{23}$ Ultimately, this Comment aims to argue that the seeming slippery slope argument deployed by Justice Scalia in his dissent to Lawrence $e^{24}$ is not a legal argument at all but, rather, a fallacy, "a clever way of exploiting a rule of collaborative discussion in order to get the best of a trusting co-participant who presumes that all other participants are following the expectations of the discussion." ${ }^{25}$ Part I will give a brief overview of the scholarship on slippery slope arguments. Part II will then proceed to illustrate how these arguments have been used, both in majority opinions and in dissents, by Supreme Court Justices, concluding with a discussion of Plessy v. Ferguson. ${ }^{26}$ In Part III, I will analyze the slippery slope arguments used in an earlier notorious case involving the status of black people, Scott $v$. Sandford, ${ }^{27}$ to make the claim that what poses as a slippery slope argument in Dred Scott is no legal argument at all. ${ }^{28}$ And finally, Part IV will posit that the dissent's slippery slope argument in Lawrence is fallacious-a "faux slope"-just as the Dred Scott argument was.

\section{THE SLIPPERY SlOPE: A REVIEW OF THE CRITICISM}

For all of its centrality to legal reasoning, surprisingly little has been written about the operation of the slippery slope-how it works and why-by legal scholars. ${ }^{29}$ But before proceeding to an analysis of

${ }^{23}$ I use the word status in the legal sense, as defined by BLACK'S LAW DiCTIONARY 1419 (7th ed. 1999): “A person's legal condition insofar as it is imposed by the law without the person's consent, as opposed to a condition that the person has acquired by agreement ...." As Wendy Brown and Janet Halley have pithily glossed this definition, " $[\mathrm{t}]$ hink king, serf, felon, wife." Wendy Brown \& Janet Halley, Introduction to LefT LEGALISM/LefT CRITIQUe 1, 36 n.3 (Wendy Brown \& Janet Halley eds., 2002).

${ }^{24} 123$ S. Ct. 2472, 2488 (2003) (Scalia, J., dissenting).

${ }^{25}$ WALTON, supra note 9 , at 26.

${ }^{26} 163$ U.S. 537 (1896).

${ }^{27} 60$ U.S. (19 How.) 393 (1857).

${ }^{28}$ It is beyond the scope of this Comment to continue this argument through all of the classes of Supreme Court cases involving status and slippery slopes. I have chosen race because in this instance the question of status is well-settled.

${ }^{29}$ The present limited state of slippery slope scholarship is discussed in note 9 , supra, and accompanying text. If required to speculate on the cause of this neglect, I would posit that legal scholars, as a rule, are more concerned with results than with process, with resolving the question "Where do we go from here?" rather than contemplating "How did we get into this mess?" Legal scholarship rarely indulges in close reading-in rhetorical analysis-of judicial opinions, which is what is called for in analysis of the slippery slope trope. 
specific cases, I think that it is useful in this Part to get a sense of where others have gone before.

\section{A. Frederick Schauer, Slippery Slopes}

The first study, a 1985 article by Frederick Schauer, is a compact and largely theoretical exposition on slippery slope arguments. ${ }^{30}$ Schauer begins with a definition of the trope in which he highlights the latent threat in the present case: " $[\mathrm{A}]$ particular act, seemingly innocuous when taken in isolation, may yet lead to a future host of similar but increasingly pernicious events." ${ }^{31}$ His aim, it seems, is to pare away types of non-slippery slope arguments so as to arrive at a "pure" slippery slope: $:^{32}$ one that "claims that permitting the instant case-a case that it concedes to be facially innocuous and that it linguistically distinguishes from the danger case-will nevertheless lead to, or increase the likelihood of, the danger case." ${ }^{33}$ Schauer eliminates types of arguments that he suggests differ substantially from pure slippery slope arguments, but his elimination process is quite brief, and scholars following him have not found his analysis terribly useful in practical application.

Schauer suggests three non-slippery slope argument frameworks: "an argument against the instant case," where the arguer is really claiming that the bottom of the slope has already been reached; $;^{34}$ "an argument directed against the excess breadth of a principle," where the person making the argument suggests that "the linguistic or doctrinal boundaries of the principle or rule" under which the instant case will be decided unintentionally "embrace the danger case"; $; 5$ and "the argument from added authority" where "granting . . . authority to a decisionmaker" to make the instant decision "increases the likelihood of a wide range of possible future events, one of which might be the danger case." ${ }^{36}$

But Schauer undermines his attempt to distinguish "the pure version of the slippery slope argument" ${ }^{37}$ when he admits that the only

\footnotetext{
${ }^{30}$ Schauer, supra note 9 .

${ }^{31} I d$. at 361-62.

${ }^{32} I d$. at 365 .

${ }^{33} I d$. at 369.

${ }^{34} I d$. at 365 .

${ }^{35} I d$. at 366 .

${ }^{36} I d$. at 367 .

${ }^{37}$ Id. at 368 .
} 
reason these "pure" arguments have any power is because language is by its nature imprecise and subject to misunderstanding. ${ }^{38}$ Given this suggestion-that in real-world application slippery slope arguments depend on mistakes and their unintended results-his cabining of at least the second of his non-slippery slope arguments (argument from excess breadth) seems erroneous.

In spite of the limitations inherent in Schauer's article, it remained the most significant attempt to examine the slippery slope in a wholly legal context until Volokh's impressive anatomy of the subject in 2003. ${ }^{39}$ Before turning to Volokh, however, I think it useful to examine Douglas Walton's excellent 1992 monograph.

\section{B. Douglas Walton, Slippery Slope Arguments}

The great strength of Walton's study of the slippery slope is his persistent use of specific examples-drawn from both legal and ethical literature-to support his generalizations. ${ }^{40}$ He suggests that all slippery slope arguments fall into three basic types: wedge arguments, sorites (or heap) arguments, and domino effect arguments. ${ }^{41}$ While in practice it is often difficult to determine into exactly which category a particular argument falls (arguers are seldom as neat in their arguments as theoreticians would like them to be) ${ }^{42}$ Walton's division of the trope into three rhetorical strategies-sometimes deployed in isolation, often converging-is interesting.

In the first of the three, the wedge argument, an arguer posits that "if some new step is taken, tried, or allowed, it will function as a precedent, which will set another precedent, and then another, until

${ }^{38}$ Id. at $370-76$.

${ }^{39}$ Volokh, supra note 2. It should be noted that a LEXIS search turns up 167 citing references to Schauer's article (as of January 28, 2005), three in judicial opinions (he is particularly popular on the Seventh Circuit) and 164 in law review articles.

${ }^{40}$ See generally WALTON, supra note 9 (presenting a critical analysis of the slippery slope argument using a case study approach). This methodology is evident from the book's very first page, where Walton notes the use of slippery slope arguments in discourse related to matters as diverse as flag burning and human embryo research. Id. at 1 .

${ }^{41} I d$. at 2.

${ }^{42}$ It's important, I think, to remember that Walton's categories are theoretical and designed to help us think about the rhetorical construct of the slippery slope argument, rather than practical designations designed to help us separate all existing slippery slope arguments into groups. In practical analysis-such as follows in the next Part of this Comment-it may be interesting to note instances where a particular type of slippery slope argument is deployed, but interesting as a point of rhetoric rather than in any useful way. 
'all hell will break loose." "43 Walton suggests that euthanasia arguments proceed along this path. ${ }^{44}$ Moving from the specific to the general, Walton notes that "the [wedge] argument starts in a clear area and proceeds towards and into a grey area, where issues are not cleanly resolved by the existing set of definitions or rules."

The second of Walton's categories, the sorites argument, also relies on vagueness, but in a fundamentally different way than the wedge argument. The basic form of sorites is simple and elegant. If one takes one grain of sand away from a heap, it's still a heap. Repeat multiple times, each time removing a single grain. But although each individual removal does not move the heap into the realm of unheapness, eventually one is left with nothing. The problem is that "heap" is a vague term, and it is impossible to draw an objective line between "heapness" and "non-heapness." ${ }^{46}$ Whereas the wedge argument begins in certainty and proceeds into a gray area, the heap argument is marked by "the use of the rejoinder 'There is no cutoff point,' when an argument contains a key term that is vague, and the proponent of the argument is having difficulty defining the term in a precise but nonarbitrary way." ${ }^{47}$ Walton locates a prime use of this mode of slippery slope argument in abortion discourse, when debating the problem of line drawing and fetal viability, where the primary questionwhen does "life" begin?-itself seems to defy definition. ${ }^{48}$

An arguer using the domino effect argument, Walton's third category, cautions her audience that "once some action is carried out, it will cause a second event, that will in turn precipitate a causal sequence of worse and worse consequences." ${ }^{\text {99 }}$ Here Walton acknowledges a problem I've already noted: ${ }^{50}$ "Characteristically, the causal slippery slope is a weak kind of argument because it predicts future contingencies, and because causality is not a matter of necessity, especially where a long sequence of causation is concerned." ${ }^{51}$ But while acknowledging the weakness of this sort of slippery slope argument,

43 WALton, supra note 9, at 2.

44 Id. at 6-7; see also LAMB, supra note 9, at 60-76 (describing the slippery slope argument against voluntary euthanasia based on the vagueness of the terms employed by the right to die argument).

${ }^{45}$ WALTON, supra note 9 , at 148.

46 Id. at $37-38$.

47 Id. at 2.

${ }^{48}$ Id. at $46-50$.

49 Id. at 2.

50 Supra text accompanying notes 16-18.

51 WALtON, supra note 9, at 102. 
Walton includes it because it tends to be deployed to spectacular effect, most notably in arguments for U.S. intervention in Vietnam: "If Vietnam falls to the Communists, they could use this base to infiltrate Cambodia. Once Cambodia falls, neighboring states could then be brought under pressure by the creeping Communist influences. Eventually, the whole of Asia could be under Communist domination. ${ }^{, 52}$

Although Walton isolates these three general types of slippery slope arguments, he does not claim that every actual argument falls into one category or another. ${ }^{53}$ Most significantly for our purposes, he suggests that the emotional thrust-and the fundamental difficultyof the parade of horribles argument is that it folds all three of these techniques into one, melding vagueness fore and aft with a giddy and attenuated causation string. ${ }^{54}$

\section{Eugene Volokh, The Mechanisms of the Slippery Slope}

In vivid contrast to both Schauer's brief theoretical survey and Walton's methodical analysis of the rhetorical structures of different sorts of slippery slope arguments, Volokh's recent work in the field is almost relentlessly practical. ${ }^{55}$ Its subtitle might have been, "You Too Can Build an Efficient Slippery Slope Argument in Ten Easy Steps!" While he does categorize slope arguments into an almost dizzying array of subtypes, ${ }^{56}$ it would be wrong, I think, to see this article as merely an anatomy, as nothing more than an examination of how slippery slopes work. Indeed, although he does devote a segment of his study to judicial slippery slopes, ${ }^{57}$ his chief interest seems to lie with advocacy groups and how they use slippery slope arguments and suffer the boomerang effect of such use: "One role of advocacy groups is to alert the public to slippery slope risks .... This strategy can be dangerous for advocacy groups because it may make them seem extrem-

Id. at 69

53 Walton's argument should not be confused with a practical cataloguing scheme for judicial opinions utilizing slippery slope arguments. That way madness lies.

${ }^{5}$ Id. at 2.

${ }^{55}$ Volokh, supra note 2.

${ }^{56}$ Volokh characterizes the arguments based on both direction of the slope, e.g., judicial-judicial, $i d$. at 1038, legislative-judicial, $i d$. at 1038, and on the effect of the slope, e.g., attitude-altering, id. at 1036, cost-lowering, id. at 1043, legal-cost-lowering, $i d$. at 1044, and "Enforcement Need" slippery slopes, $i d$. at 1051. The text of the article is over 100 pages long, and it would not be useful to cite each and every one of Volokh's numerous categories here.

${ }^{57}$ Id. at $1064-71$. 
ist. ${ }^{, 58}$ But, Volokh argues, because advocacy groups are aware of the true risks inherent in various types of slippery slopes, these groups are justified in their extreme behavior-in fact, extreme behavior is their only possible effective response. ${ }^{59}$ And his true aim seems to be to present advocacy groups with a sort of roadmap, a guide to the efficient construction (and rebuttal, as the need arises) of slippery slope arguments. ${ }^{60}$ It remains to be seen whether advocacy groups are able to make practical use of Professor Volokh's suggestions.

\section{SLIPPERY SlOPE ARGUMENTS IN U.S. SUPREME COURT OPINIONS}

Numerous Supreme Court opinions make use of slippery slope arguments, for a variety of reasons, to various effects. In this Part, it is my aim to survey a few of the different deployments of slippery slope arguments, framed by some of the settings in which these arguments recur. This survey is by no means exhaustive; it is meant only to illustrate that slippery slope arguments-arguments that are completely legitimate legal arguments-are used regularly in both majority opinions and dissents.

${ }^{58} I d$. at 1038 .

${ }^{59} I d$. at $1129-30$.

${ }^{60} I d$. at 1127-35. As Volokh exhorts his readers towards the end of the article: Understanding slippery slope mechanisms can also help us think about how to avoid the slippery slope inefficiency-the situation where a potentially valuable option $A$, which would pass if considered solely on its own merits, is defeated because of swing voters' reasonable fears that $A$ will lead to $B$. Various tools can help prevent this slippery slope inefficiency by decreasing the chance that $A$ could help bring about $B$, and thus increasing the chance that $A$ will be enacted. This Article has discussed three such tools: (1) strong constitutional protection of substantive rights; (2) weak rational basis review under equal protection rules; and (3) proposals in which both sides win something and lose something, thus preventing either side from gaining political momentum. We may want to look for other such tools.

For instance, to what extent can interest groups use their permanent presence, and their continuing relationships with legislators and members of opposing advocacy groups, to work out deals that can prevent slippery slope inefficiencies-deals that unorganized voters could not themselves make? Can such deals be reliable commitments, even though they aren't constitutionally entrenched, or is there too much danger that future legislatures will overturn the deals?

Id. at 1131-32 (footnote omitted and italicization added). 


\section{A. Right to Die Cases}

Two cases engaging different aspects of the "right to die" debate include noteworthy slippery slope arguments. In Cruzan v. Director, Missouri Department of Health, ${ }^{61}$ the Court held that it is constitutional for a state to require clear and convincing evidence of an incompetent patient's wishes before discontinuing life-sustaining hydration and nutrition at the request of her family. ${ }^{62}$ In his concurring opinion, Justice Scalia denies that the Court's decision is based on its unwillingness to negotiate the "right to die" slope; indeed, he suggests that the Court's decision does precisely that-it draws a line, locating the nonarbitrary stopping point where a state's democratically elected legislature has designated it. ${ }^{63}$

Seven years later, in Washington v. Glucksberg, ${ }^{64}$ the Court upheld a state ban on physician-assisted suicide for a mentally competent, terminally ill adult patient on the ground that it was rationally related to legitimate state interests. ${ }^{65}$ Concurring with the majority, Justice Souter employs the slippery slope argument-a classic sorites paradox $^{66}$ - to warn that once the door to physician-assisted suicide is opened, "the line between the ill and dying, and between the responsible and the unduly influenced" would inevitably become blurred. ${ }^{67}$

${ }^{61} 497$ U.S. 261 (1990).

${ }^{62} I d$. at $286-87$.

63 As formulated by Justice Scalia:

Are there, then, no reasonable and humane limits that ought not to be exceeded in requiring an individual to preserve his own life? There obviously are .... What assures us that those limits will not be exceeded is the same constitutional guarantee that is the source of most of our protection-what protects us, for example, from being assessed a tax of $100 \%$ of our income above the subsistence level, from being forbidden to drive cars, or from being required to send our children to school for 10 hours a day, none of which horribles are categorically prohibited by the Constitution. Our salvation is the Equal Protection Clause, which requires the democratic majority to accept for themselves and their loved ones what they impose on you and me.

Id. at 300 (Scalia, J., concurring).

${ }^{64}$ 521 U.S. 702 (1997)

${ }^{65}$ Id. at 735 .

${ }^{66}$ See supra text accompanying notes 46-48 (describing the paradox of the heap).

${ }^{67}$ As Justice Souter says:

The argument is that a progression would occur, obscuring the line between the ill and the dying, and between the responsible and the unduly influenced, until ultimately doctors and perhaps others would abuse a limited freedom to aid suicides by yielding to the impulse to end another's suffering under conditions going beyond the narrow limits the respondents propose. The State thus argues, essentially, that respondents' claim is not as narrow as it sounds, simply because no recognition of the interest they assert could be limited to 
It is not insignificant, however, that while the majority opinion acknowledges this slippery slope argument and relies on it, in part, as a basis for the decision, the insufficiency of the argument-and its tendency to use fear of a future case to limit a right being asserted in the present-is acknowledged as well. ${ }^{68}$

\section{B. IRS Cases}

While less spectacular, perhaps, than the "right to die" problem, two cases involving federal tax law provide straightforward examples of how majority opinions at times utilize-and at times undermineslippery slope arguments in their reasoning. In Commissioner v. Culbertson, ${ }^{69}$ the Court ruled that intent to contribute capital or labor sometime in the future is insufficient to make someone a partner in a business for tax purposes. ${ }^{70}$ The majority punctuates its opinion with a slippery slope argument: if in the present case we allow intended future conduct to dictate tax liability, in some future case we will be forced to allow a newborn child to be named a partner in a business, for tax purposes. ${ }^{71}$

By contrast, in Dickman v. Commissioner, ${ }^{72}$ the Court rejected a slippery slope argument as it affirmed the Eleventh Circuit's ruling that interest-free family loans are subject to federal gift tax statutes. ${ }^{73}$ The petitioner argued-in slippery slope fashion-that this rule:

[W] ould elevate to the status of taxable gifts such commonplace transactions as a loan of the proverbial cup of sugar to a neighbor or a loan of lunch money to a colleague. Petitioners urge that such a result is an un-

vindicating those interests and affecting no others.

Glucksberg, 521 U.S. at 783 (Souter, J., concurring).

68 "We agree that the case for a slippery slope has been made out, but ... we also recognize the reasonableness of the widely expressed skepticism about the lack of a principled basis for confining the right." Id. at 733 n.23 (opinion of Rehnquist, C.J.).

${ }^{69} 337$ U.S. 733 (1949).

${ }^{70}$ Id. at 740 .

${ }^{71}$ As Chief Justice Vinson writes:

The vagaries of human experience preclude reliance upon even good faith intent as to future conduct as a basis for the present taxation of income. ... The reductio ad absurdum of the theory that children may be partners with their parents before they are capable of being entrusted with the disposition of partnership funds or of contributing substantial services occurred ... where a taxpayer made his son a partner in his accounting firm the day the son was born.

Id. at $740 \&$ n. 8 .

${ }^{72} 465$ U.S. 330 (1984).

73 Id. at 333 . 
tenable intrusion by the Government into cherished zones of privacy ... ${ }^{74}$

But the Court disagreed, arguing that tax law, with its provisions for gifts, has built-in line drawing that would preclude a progression down that slope:

[T] he tax law provides liberally for gifts to both family members and others; within the limits of the prescribed statutory exemptions, even substantial gifts may be entirely tax free ... . These generous exclusions, exceptions, and credits clearly absorb the sorts of de minimis gifts petitioners envision and render illusory the administrative problems that petitioners perceive in their "parade of horribles.",

That is, the statute itself forecloses the possibility of the undesirable future case. ${ }^{76}$

\section{The Inner Workings of the Law}

Slippery slope arguments enjoy liberal use in cases involving line drawing with regard to the procedural operation of the courts and the criminal justice system. ${ }^{77}$ In Colgrove v. Battin ${ }^{78}$ Justice Marshall uses a sorites paradox to underscore the fundamental arbitrariness of jury size, pointing out that there is no way to define a nonarbitrary number of jurors that compose a jury (as opposed to merely a group of people in a jury room):

One could, of course, define the term "jury" as being a body of six or more laymen. But the line between five and six would then be just as arbitrary as the line between 11 and 12 . There is no way by reference to abstract principle or "function" that one can determine that six is "enough," five is "too small," and 20 "too large." These evaluations can only be made by reference to a hypothetical ideal jury of some arbitrarily chosen size. All one can say is that a jury of six functions less like a jury of 12 than would a jury of, say eight, but more like a jury of 12 than would a jury of three. Although I think it clear that my Brethren would reject, for example, a jury of one, the Court does not begin to tell us how it would go about drawing a line in a nonarbitrary fashion, and it is obvi-

${ }^{74} I d$. at $340-41$.

${ }^{75} I d$. at $341-42$.

${ }^{76}$ Of course, it might well be argued that the Court's interpretation of the statute in the present case destabilizes the very line drawing upon which it relies.

77 The cases that follow are merely presented as exemplars and are by no means intended as an exhaustive survey.

${ }^{78} 413$ U.S. 149, 150-51 (1973) (affirming the lower court decision that the Seventh Amendment was not violated by a six-member jury in a federal diversity case). 
ous that in matters of degree of this kind, nonarbitrary line drawing is a logical impossibility.

Justice Marshall caps his argument with a warning of the dangers inherent in tinkering with this number for the sake of expedience: "[A]s dockets become more crowded and pressures on jury trials grow, who is to say that some future Court will not find three, or two, or one a number large enough to satisfy its unexplicated sense of justice?" ${ }^{80}$

Similarly, the majority in McCleskey $v . \mathrm{Kemp}^{81}$ employs a wedge argument $^{82}$ to justify its holding that a statistical study did not present sufficient evidence that Georgia's capital sentencing process was administered in a racially discriminatory way, in violation of the Fourteenth Amendment. ${ }^{83}$ Had the Court found in favor of McCleskey, Justice Powell explains, the floodgates would open and "we could soon be faced with similar claims as to other types of penalty. ... [T] here is no limiting principle to the type of challenge brought by McCleskey." ${ }^{84}$ Justice Brennan's dissent critiques the majority's slippery slope argument, pointing out that at its core it "seems to suggest a fear of too much justice."

Moving from the sentencing process to jury selection, in Holland v. Illinois ${ }^{86}$ Justice Scalia locates the wholesale "elimination of peremptory challenges" ${ }^{\$ 7}$ at the bottom of the slope the Court would tread should it preclude a prosecutor from using his peremptory challenges to strike all the black venire members in the trial of a white man. ${ }^{88}$

${ }^{79} I d$. at 180-81 (Marshall, J., dissenting) (footnotes omitted).

${ }^{80}$ Id. at 181 .

81481 U.S. 279 (1987).

${ }^{82}$ See supra text accompanying notes 43-45 (describing the rhetorical structure of the wedge argument). "McCleskey's claim, taken to its logical conclusion, throws into serious question the principles that underlie our entire criminal justice system." McCleskey, 481 U.S. at 314-15.

${ }^{83}$ McCleskey, 481 U.S. at 297.

${ }^{84} I d$. at 315-18 (footnotes omitted); cf. Toby J. Stern, Comment, Federal Judges and Fearing the "Floodgates of Litigation," 6 U. PA. J. CONST. L. 377, 378-79 (2003) (anatomizing the use of the "floodgates" argument as a means of reducing judicial caseloads).

${ }^{85}$ McCleskey, 481 U.S. at 339 (Brennan, J., dissenting). Justice Brennan goes a step further, suggesting, albeit obliquely, that the majority's concern for the slippery slope might be serving as a smokescreen for racism: "Yet surely the majority would acknowledge that if striking evidence indicated that other minority groups, or women, or even persons with blond hair, were disproportionately sentenced to death, such a state of affairs would be repugnant to deeply rooted conceptions of fairness." Id.

${ }^{86} 493$ U.S. 474 (1990).

${ }^{87}$ Id. at 484 (quoting Lockhart v. McCree, 476 U.S. 162, 178 (1986)).

${ }^{88} I d$. at 487 . 
Justice Scalia punctuates his discussion by arguing that "[h]is Sixth Amendment claim would be just as strong if the object of the exclusion had been, not blacks, but postmen, or lawyers, or clergymen, or any number of other identifiable groups. ${ }^{, 89}$

Finally, in Atwater v. City of Lago Vista ${ }^{90}$ Justice O'Connor's dissent cautions the Court of the "potentially serious consequences for the everyday lives of Americans" inscribed in the Court's per se rule that the Fourth Amendment does not forbid warrantless custodial arrest for offenses punishable only by a fine. ${ }^{91}$ Justice O'Connor warns that this new rule will give law enforcement personnel broad discretion to search or arrest people who have committed any one of numerous fine-only criminal offenses. ${ }^{92}$

A broad range of conduct falls into the category of fine-only misdemeanors. In Texas alone, for example, disobeying any sort of traffic warning sign is a misdemeanor punishable only by fine, as is failing to pay a highway toll, and driving with expired license plates. Nor are fineonly crimes limited to the traffic context. In several States, for example, littering is a criminal offense punishable only by fine.

And she makes it clear that the root of her concern is not that litterers or toll-runners might be arrested for the offenses they've actually committed: " $[\mathrm{A}] \mathrm{s}$ the recent debate over racial profiling demonstrates all too clearly, a relatively minor traffic infraction may often serve as an excuse for stopping and harassing an individual. After today, the arsenal available to any officer extends to a full arrest and the searches permissible concomitant to that arrest." ${ }^{94}$

\section{Plessy v. Ferguson}

Justice Harlan's dissent in Plessy v. Ferguson ${ }^{95}$ is a trenchant reminder that slippery slope arguments, when properly deployed, are

Id. at 486 .

532 U.S. 318 (2001).

${ }^{91} I d$. at 371 (O'Connor, J., dissenting).

${ }^{92}$ Id. at 372 .

${ }^{93}$ Id. (citations omitted).

${ }^{94} I d$. For a parallel slippery slope dissent in an analogous case, see Harmelin $v$. Michigan, 501 U.S. 957, 994-96 (1991), which held that a punishment disproportionate to a crime is not per se cruel and unusual. "Justice Scalia's analysis [in the majority opinion] ... provides no mechanism for addressing a situation ... in which a legislature makes overtime parking a felony punishable by life imprisonment. . . [A]bsent a proportionality guarantee, there would be no basis for deciding such cases should they arise." Id. at 1018 (White, J., dissenting).

163 U.S. 537 (1896). 
bona fide legal arguments making use of the tools of analogy and precedent; the Court ignores such arguments at its own peril. ${ }^{96}$ In Plessy, the Court held that a law mandating separate but equal accommodations for white and black railroad passengers was not in violation of the Fourteenth Amendment to the U.S. Constitution. ${ }^{97}$ Justice Harlan's was the lone dissenting voice, warning-Cassandra-likeof the slippery slope below this ruling: ${ }^{98}$

If a State can prescribe, as a rule of civil conduct, that whites and blacks shall not travel as passengers in the same railroad coach, why may it not so regulate the use of the streets of its cities and towns as to compel white citizens to keep on one side of a street and black citizens to keep on the other? Why may it not, upon like grounds, punish whites and blacks who ride together in street cars or in open vehicles on a public road or street? Why may it not require sheriffs to assign whites to one side of a court-room and blacks to the other? And why may it not also prohibit the commingling of the two races in the galleries of legislative halls or in public assemblages convened for the consideration of the political questions of the day? Further, if this statute of Louisiana is consistent with the personal liberty of citizens, why may not the State require the separation in railroad coaches of native and naturalized citizens of the United States, or of Protestants and Roman Catholics? ${ }^{99}$

It is, of course, a truism that by the end of the first decade of the twentieth century, "what is widely called 'Jim Crow' applied to every aspect of Southern public life." ${ }^{100}$ This vicious outcome, though not the necessary result of the present case, was a logical, rational, legal result of Plessy's rule, predicted in the concatenations of Justice Harlan's wedge argument, "Why may it not?"

The Plessy dissent may be the most spectacular example of the slippery slope argument as a logically true legal argument-where the slope actually played out and the present case led to the warned-of future cases through the operation of stare decisis. But in each of the cases surveyed in this Part, slippery slope arguments are engaged in legitimate ways, that is, as sound legal arguments and not simply as

${ }^{96}$ As Justice Scalia cautioned an audience of law students, in reference to Justice Harlan's dissent in Plessy, "But do not scoff at the 'parade of horribles' in principle, as though the marchers in fact never materialize." Scalia, supra note 22, at 592.

Plessy, 163 U.S. at 550-51. See generally Barbara Y. Welke, Beyond Plessy: Space, Status, and Race in the Era of Jim Crow, 2000 UTAH L. REV. 267 (discussing the impact of the Plessy decision and Jim Crow laws on the status of black people).

${ }^{98}$ Justice Brewer recused himself. 163 U.S. at 564.

${ }^{99}$ Id. at 557-58 (Harlan, J., dissenting).

${ }^{100}$ Welke, supra note 97 , at 267-68. For reference to the applicable statutes, see $i d$. nn.3-5. 
appeals to emotion. In all of these arguments, the slippery slope concern is that a rule, once constructed, may not be easily restricted to its original context. In some cases, the majority argues that the line can be drawn; in others, not. In both "right to die" cases, concurring opinions display an acute awareness of the slippery slope, with Justice Scalia in Cruzan confident that the Court was drawing a bright line that would restrain the future cases, and Justice Souter in Glucksberg cautious when negotiating the boundary between life and death. ${ }^{101}$

The slippery slope, line drawing, and stare decisis come into similar play in the IRS cases. In Culbertson, the Court determined that there was no way to tailor the concept of business partnership based on an intended future business contribution sufficiently narrowly to preclude the doctrine from encompassing a business owner's newborn child; but the Dickman Court found a bright line in the language of the statute governing that case. ${ }^{102}$

And finally, in the procedural cases, slippery slope arguments are used by the Court to underscore the strengths and weaknesses of rules governing jury selection, sentencing, and criminal procedure. In Colgrove, the dissent uses a slippery slope argument to illustrate the fundamentally arbitrary nature of jury size and, hence, the impossibility of line drawing and the temptation of moving towards smaller juries in the interest of efficient case management, once the Court rules that six-member juries do not violate the Seventh Amendment. The desire to protect the judiciary from opening the floodgates of litigation is the rationale behind the slippery slope argument deployed in McCleskey, where the Court declined to label a state court's capital sentencing process racially discriminatory lest its ruling unleash challenges to all sentencing processes; the dissent agreed that this was a likely result, viewing the slope as the path of justice rather than as a cause for alarm. And the dissent in Atwater warned that giving police the per se authority to arrest for fine-only offenses was a step onto a slippery slope that would end with minor offenses being used as pretext for all manner of previously unconstitutional searches and seizures. ${ }^{103}$

\footnotetext{
${ }^{101}$ See supra notes 61-68 and accompanying text for a full discussion of the "right to die" cases.

${ }^{102}$ See supra notes 69-76 and accompanying text for a full discussion of the IRS cases.

${ }^{103}$ See supra notes 77-94 and accompanying text for a full discussion of the procedural cases.
} 


\section{STATUS AND SLAVERY}

The very act of naming things in the world shapes the way we think about and treat them. For instance, if one labels an entity a person, it suggests that that entity has certain intrinsic rights, independent of one's relationship with it. On the other hand, if one frames something as "property," a wholly different way of thinking arises. Property does not have any intrinsic rights of its own . . . .

$$
\text { -Kayhan Parsi }{ }^{104}
$$

Not all arguments in the form of the slippery slope are, in fact, legal arguments. For example, in order for a slippery slope argument to be valid in the legal sense, it must proceed from the legal world as it would be if the present case were decided contrary to the arguer's wishes. If the arguer constructs her argument on some other basisfor instance, ignoring the changes to the legal landscape effected by the present case-her slippery slope argument is a rhetorical fallacy with no legal legs on which to stand. And when the person making such a "faux slope" argument is a Supreme Court Justice, a highly skilled rhetorician, the cost may be very high indeed.

Possibly the most transparent "faux slope" argument in U.S. Supreme Court history is Plessy's antebellum bookend, Scott v. Sandford. ${ }^{105}$ Its most infamous holding — that allowing the Missouri Compromise to deprive a slaveowner of his slave/property violated due process ${ }^{106}$ is argued by means of what seems to be a slippery slope argument. As Chief Justice Taney's majority opinion counsels:

And if the Constitution recognizes the right of property of the master in a slave, and makes no distinction between that description of property and other property owned by a citizen, no tribunal, acting under the authority of the United States ... has a right to draw such a distinction, or deny to it the benefit of the provisions and guarantees which have been provided for the protection of private property against the encroachments of the Government. ${ }^{107}$

${ }^{104}$ Kayhan Parsi, Metaphorical Imagination: The Moral and Legal Status of Fetuses and Embryos, 2 DePaul J. Health Care L. 703, 710 (1999).

${ }^{105} 60$ U.S. (19 How.) 393 (1857).

106 " $[\mathrm{A}] \mathrm{n}$ act of Congress which deprives a citizen of the United States of his liberty or property, merely because he came himself or brought his property into a particular Territory of the United States . . could hardly be dignified with the name of due process of law." Id. at 450 .

${ }^{107} I d$. at 451 . The same sentiment is echoed, in even stronger language, by Justice Catron's concurrence: "If Congress could prohibit one species of property, lawful 
That is, the majority is here anchoring its holding at the summit of a slippery slope, at whose bottom may be found the dangerous future result of ad hoc seizure of private property by the government.

But as I suggested above, this is a faux slope. ${ }^{108}$ Had the Court found in favor of Dred Scott, had it changed the status of slave from property to person, the holding would have had no bearing whatsoever on general property rights; the present case could not logically have been the first step onto a slippery slope leading down towards the government encroachment of Chief Justice Taney's nightmare scenario. Because, as the dissenters suggest, ${ }^{109}$ if the Court had found for Dred Scott, the rule would have applied to him not as property but as a person, not as a slave but as a free man. The Court would have been liberating not property but, rather, a person. And since in that legal world Scott would not have had the status of property, there is no way-either by analogy or by precedent-that Scott could have led to the horribles threatened by the majority.

\section{STATUS AND SODOMITES ${ }^{110}$}

Lawrence $v$. Texas ${ }^{111}$ is a tissue of slippery slope arguments and responses thereto. ${ }^{112}$ Given that slippery slope arguments have so often

throughout Louisiana when it was acquired, and lawful in the State from whence it was brought, so Congrsss [sic] might exclude any or all property." Id. at 527 (Catron, J., concurring).

${ }^{108}$ See supra note 23 and accompanying text (theorizing a link between the faux slope and cases involving status).

109 "Does not this show that property in a human being does not arise from nature or from the common law, but, in the language of this court, 'it is a mere municipal regulation, founded upon and limited to the range of the territorial laws?" 60 U.S. (19 How.) at 549 (McLean, J., dissenting) (quoting Prigg v. Pennsylvania, 41 U.S. (16 Pet.) 539, 611 (1842)). "Slavery, being contrary to natural right, is created only by municipal law. This is not only plain in itself, and agreed by all writers on the subject, but is inferable from the Constitution, and has been explicitly declared by this court." Id. at 624 (Curtis, J., dissenting).

${ }^{110}$ In this segue from slavery to sodomy, it is not my intent to suggest that the jurisprudence of race is analogous to the jurisprudence of gender and/or sexuality. Indeed, there are compelling reasons for distancing queer law from race law. See Janet E. Halley, "Like Race" Arguments, in WHAT's LEFT OF THEORY? 40, 54 (Judith Butler et al. eds., 2000) (analyzing the arguments against positioning queer-identity jurisprudence as analogous to race jurisprudence). Nevertheless, there are telling parallels between the slippery slope arguments in these cases that make this juxtaposition fruitful.

123 S. Ct. 2472 (2003)

${ }^{112}$ And the present discussion does not presume to address all—or even most—of the aspects of the case. My concern here is to establish the majority's ruling on the changed status of gay men and lesbians and then to argue that Justice Scalia has constructed a faux slope based on his denial of the status shift. A number of scholars have 
been deployed to restrict the rights of minorities, it is poetically just that at the core of the majority opinion-decriminalizing private, consensual sodomy between adult same-sex couples and overturning the Court's decision in Bowers v. Hardwick ${ }^{113}$-lies a slippery slope argument by means of which the status of gay men and lesbians in the United States is redefined. Justice Kennedy situates Bowers at the head of a slippery slope, arguing that while sodomy laws claim to do no more than restrict a single, particular act of sexual intimacy, in fact the effect of that act's criminalization is the blurring of the line between act and actor, between conduct and status. While the present case is only the criminalization of a single act, the unpleasant and undesired future result is the unconstitutional restriction of the liberty of all gay men and lesbians. ${ }^{114}$ As Justice Kennedy writes:

To say that the issue in Bowers was simply the right to engage in certain sexual conduct demeans the claim the individual put forward, just as it would demean a married couple were it to be said marriage is simply about the right to have sexual intercourse. The laws involved in Bowers and here are, to be sure, statutes that purport to do no more than prohibit a particular sexual act. Their penalties and purposes, though, have more far-reaching consequences, touching upon the most private human conduct, sexual behavior, and in the most private of places, the home. The statutes do seek to control a personal relationship that, whether or not entitled to formal recognition in the law, is within the liberty of persons to choose without being punished as criminals. ${ }^{115}$

That is, sodomy laws-taken together with the Bowers ruling that defined (and then denied) a homosexual's liberty interest narrowly as

offered incisive and insightful readings of the Lawrence decision's meaning and potential impact. See generally Laurence H. Tribe, Lawrence v. Texas: The "Fundamental Right" that Dare Not Speak Its Name, 117 HARV. L. REV. 1893 (2004) (tracing the development of substantive due process jurisprudence from Bowers through Lawrence and speculating upon the doctrine's future); Cass R. Sunstein, What Did Lawrence Hold? Of Autonomy, Desuetude, Sexuality, and Marriage, 2003 Sup. CT. REv. 27 (suggesting that ultimately a doctrine of procedural-rather than substantive-due process is the engine moving the majority); Mary Anne Case, Of "This" and "That" in Lawrence v. Texas, 2003 SuP. CT. REv. 75 (drawing attention to the limiting effects of the seemingly deliberate ambiguity of many of the majority opinion's key passages); William N. Eskridge, Jr., Lawrence's Jurisprudence of Tolerance: Judicial Review to Lower the Stakes of Identity Politics, 88 MINN. L. REV. 1021 (2004) (surveying the history and implications of Lawrence as a conservative, libertarian opinion championing tolerance for, rather than acceptance of, homosexuals); Nan D. Hunter, Sexual Orientation and the Paradox of Heightened Scrutiny, 102 MiCH. L. REV. 1528 (2004) (demonstrating that the decriminalization of homosexual intimate conduct has ratcheted up state regulation of homosexuality).

113478 U.S. 186 (1986).

${ }^{114}$ Lawrence, 123 S. Ct. at 2478.

${ }^{115}$ Id. (emphasis added). 
"whether the Federal Constitution confers a fundamental right upon homosexuals to engage in sodomy," duct. And that criminalization, Justice Kennedy argues, begins a slide down a slope that ends with the stigmatization of homosexual status: "When homosexual conduct is made criminal by the law of the State, that declaration in and of itself is an invitation to subject homosexual persons to discrimination both in the public and in the private spheres." ${ }^{117}$ Ultimately, the Lawrence majority rolls back the Bowers Court's narrow definition of an adult's sexual privacy liberty interest in favor of a more expansive one that permits "adults [to] choose to enter upon this relationship in the confines of their homes and their own private lives and still retain their dignity as free persons." 118

Justice Scalia's dissent in Lawrence layers slippery slope argument upon slippery slope argument. ${ }^{19}$ But it is a single, small section of his opinion that is of interest here and that reveals at least part of the dissent to be a faux slope. Justice Scalia warns us, loudly, that "[ $\mathrm{t}] \mathrm{he}$ impossibility of distinguishing homosexuality from other traditional 'morals' offenses" ${ }^{\prime 20}$ sets the majority rule at the top of a slope that will invariably lead to the overturning of " $[\mathrm{s}]$ tate laws against bigamy, same-sex marriage, adult incest, prostitution, masturbation, adultery, fornication, bestiality, and obscenity." ${ }^{\prime 21}$ But I would argue that one of the things that the majority does is precisely to distinguish homosexuality-that is, the status-from criminality by grouping homosexuals

116 Bowers, 478 U.S. at 190.

117 Lawrence, $123 \mathrm{~S}$. Ct. at 2482. Laurence Tribe expresses this most eloquently when he writes:

The outlawed acts-visualized in ways that obscure their similarity to what most sexually active adults themselves routinely do-come to represent human identities, and this reductionist conflation of ostracized identity with outlawed act in turn reinforces the vicious cycle of distancing and stigma that preserves the equilibrium of oppression in one of the several distinct dynamics at play in the legal construction of social hierarchy. Tribe, supra note 112, at 1896.

118123 S. Ct. at 2478. As Bernard Harcourt suggests, "The loudest message that Lawrence conveys is: 'what two consenting mature adults do in their own bedroom (as long as they are not hurting anyone) is none of the government's business." Bernard E. Harcourt, Supreme Court Review-Forward: "You Are Entering a Gay and Lesbian Free Zone": On the Radical Dissents of Justice Scalia and Other (Post-) Queers [Raising Questions About Lawrence, Sex Wars, and the Criminal Law], 94 J. CRIM. L. \& CRIminology 503, 511 (2004).

${ }^{119}$ There is much to be said elsewhere about the rhetoric of his opinion, particularly his bitter and sardonic use of Roe v. Wade, 410 U.S. 113 (1973), and Planned Parenthood of Southeastern Pennsylvania v. Casey, 505 U.S. 833 (1992).

${ }_{120}$ Lawrence, 123 S. Ct. at 2490 (emphasis added) (Scalia, J., dissenting).

121 Id. 
with heterosexuals under the rubric of "free persons." ${ }^{122}$ That is, by deciding the case on due process grounds rather than on equal protection grounds (as per Justice O'Connor's concurrence), the majority would seem to say precisely that the issue here is not whether a sodomy law can treat homosexuals differently from heterosexuals. Rather, the majority makes a statement about a right-of sexual privacy-that accrues to all citizens, gay and straight. The Lawrence majority says that it is unconstitutional to withhold this right from certain citizens based on status.

But each of the characters in Justice Scalia's parade of horribles is an act, a mode of conduct, presumably forbidden somewhere in the United States. ${ }^{123}$ None of them is related to homosexuality per se, and none of them could arguably be a matter of status. ${ }^{124}$ Bigamy, bestiality, fornication, and their fellow travelers in Justice Scalia's litany are all descriptors of behavior. One earns those labels by doing some act. But homosexuality is status and not conduct; it describes a state of being rather than a particular act. The offenses in Justice Scalia's parade of horribles are no more likely to be held unconstitutional today than they were a year ago, when only heterosexual status carried the privilege of sexual privacy. Broadening that right to include gay men and lesbians has not set the Court on the libertarian slippery slope that so infuriates Justice Scalia; on the contrary, it serves to level the slope that led courts to elide "homosexual" and "criminal."

To put this another way: Justice Scalia warns that Lawrence's expansion of the fundamental right to sexual privacy is the first step along a slippery slope that will make it impossible for states to criminalize other private sexual acts. In fact, however, because this case

${ }^{122}$ Id. at 2478 (majority opinion).

${ }^{123}$ The question of whether the criminalization of any one of those acts has truly been left without a rational basis in Lawrence's wake is beyond the scope of this Comment and is yet another angle from which to critique Justice Scalia's slope-building technique. For an analysis of where state laws criminalizing incest stand in the postLawrence era, see Brett H. McDonnell, Is Incest Next?, 10 CARdozo Women's L.J. 337, 348-55 (2004).

${ }^{124}$ Same-sex civil marriage, not one of Justice Scalia's "horribles" but included later in his dissent as yet another undesired future case, Lawrence, 123 S. Ct. at 2496, is certainly a question of status. But even when Bowers was still good law, the withholding of marriage-or at least the rights and privileges of marriage-from same-sex couples was ruled unconstitutional under the state constitutions of Hawaii, Baehr v. Lewin, 852 P.2d 44, 66 (Haw. 1993); Alaska, Brause v. Bureau of Vital Statistics, No. 3AN-95-6562 CI (Alaska Super. Ct. Feb. 27, 1998), aff'd, Brause v. Dep't of Health \& Soc. Servs., 21 P.3d 357 (Alaska 2001); and Vermont, Baker v. State, 744 A.2d 864, 889 (Vt. 1999). So it is unconvincing to argue that, in overruling Bowers, Lawrence marks the beginning of a slide down that slope. 
turns on a question of status, I would argue that the fundamental right to sexual privacy is unchanged per se. It still is the right of two (and not three or four or seven) consenting (and not coerced by any physical or emotional means) non-consanguine (and not siblings or parent and child) adults (and not an adult with a child or an adult with an animal) to choose to engage in a private, sexual relationship. All that is changed is that the definition of "adult" has been read to include all adults, irrespective of sexual orientation. ${ }^{125}$ Any relationship that doesn't track the fundamental right—and all of Justice Scalia's horribles fall into this category-could still be criminalized by a state without Lawrence creating a constitutional block. Justice Scalia makes the claim that the right has changed, which it has not.

In Dred Scott, it was the dissent that recognized that a rule that changed the status of a black man from property to human being did nothing to endanger private property in general. In Lawrence, the majority recognized that extending sexual privacy to all citizens, irrespective of sexual orientation, did nothing to alter the criminality of incest, bestiality, and polygamy.

\section{CONCLUSION}

Slippery slope arguments are highly effective legal arguments when reasonably and logically deployed. But it may be difficult to distinguish true slopes from false, because the slippery slope trope uses analogy and precedent, legal tools so familiar that they are rendered nearly invisible in judicial opinions. This Comment begins an exploration of the relationship between shifts in status and faux slopes so as to expose both the fallacies in those arguments and the dangers inherent in them. The unexamined slippery slope argument may in fact be a Trojan horse for the jurisprudence of hate.

${ }^{125}$ I would posit that this is what Justice Kennedy means when he says that although the majority was deciding Lawrence on due process and not equal protection grounds, the decision "advances both interests." Lawrence, 123 S. Ct. at 2482. 